\title{
Evaluating Realism and Liberalism: Which School of Thought Better Explains World Politics?
}

\author{
Guanzhuo Chen ${ }^{1 *}$, Chenlei Zhu², Xiaoze Zhang ${ }^{3}$, Chuqing Qiao ${ }^{4}$, Yuning Han $^{5}$ \\ ${ }^{1}$ College of Arts and Science, New York University, 100 Washington Square E, New York, New York, 10003, United \\ States,gc2740@nyu.edu. \\ ${ }^{2}$ Ohio State University, 281 W Lane Avenue, Columbus, Ohio, 43210, United States. \\ 3. Beijing Aidi International Education Park, 7 louzizhuanng Road, Chaoyang District, Beijing, China. \\ ${ }^{4}$ The Experimental High School Attached to Beijing Normal University, 14th Erlong Road, Xicheng District, Beijing, \\ China. \\ 5. Maumee Valley Country Day School, 1715 South Reynolds Rd, Toledo, Ohio, 43614, United States.
}

\begin{abstract}
Realism and liberalism are two of the most competitive and applicable international relations theories that frequently provoke scholar confrontations. The two world-wars that took place last century prone to be a realist military expansion by Germany. The establishment of United Nations, instead, tends to become a liberal organization that promotes cooperation and palliate the occurrence of inter-state war. This paper primarily examines which of these two mainstream international relations theories better explains world politics. This paper mainly argues that realism better demonstrates world politics because regardless of how optimistic the three liberal variant theories (Economic interdependence, Democratic Peace Theory, International Institutions) have depicted the world, conflict is always possible to occur and each of these three variants is internally flawed with examples substantiating the deficiencies. Compared with liberalism, realism is a more reliable theory that accurately demonstrates the reality of world politics.
\end{abstract}

Keywords: realism, liberalism, economic interdependence, democratic peace theory, international institutions

\section{INTRODUCTION}

Realism and liberalism are two of the most longestablished and theoretically riveling international relations theories in the contemporary era. Even though sharing different assumptions about the international community, the two seemingly opposing theories each can distinctively explain the political interactions and events in the international community. For instance, realism provides convincing explanations of the past two World Wars which occurred in early and mid-twentieth centuries. Realism argues that the perpetuating competition between states will possibly evoke armed conflicts. Liberalism, being less war-prone, successfully illustrates the importance of the United Nations, NATO, and other international institutions because it argues that these institutions are eligible to facilitate cooperation and peace among states and reduce the possibility of conflicts. Indeed, the world had witnessed a more peaceful and cooperative international community in the post-war era. Since the two competing theories provided different understanding about world politics, scholars from each school of thought had confronted each other for decades, attempting to repudiate the arguments of the opposing side to attain the supremacy of their theories.

As the debate escalates, it inevitably generates the question of which theory better explains world politics. Hence, this paper primarily examines the two competing theories and attempts to provide a conclusion of which international theory better explains world politics. We argue that realism better explains world politics because the liberal explanation of world politics is flawed in logic, and there is empirical evidence to verify that war is still possible under the liberal-depicted international community. First, we will first provide our definition of the key terms. Second, we will briefly lay out the explanation of the three cardinal liberal theories (economic interdependence, democratic peace theory, and international institutions) on world politics. Third, we will winnow the embedded logical flaws within the explanation and provide empirical evidence of the 
pertaining likelihood of conflicts to argue for realism as the better theory. Fourth, we will present the counterarguments from liberals and the repudiation from realism in the discussion to further advance realism as the better theory. Last, we will conclude the theory by reiterating our arguments and discussing the implications and prediction of the future world politics. We will primarily utilize examples from contemporary world politics as valid empirical evidence to support our arguments.

\section{GROUNDWORK}

It is necessary to clarify that we are examining which international relations theory better explains world politics. We are not refuting the premises of theories but examining and deciding which theory is better. Before presenting arguments, it is necessary to clearly illustrate the definitions of the key terms. We define world politics as a discipline which discusses state interactions and state behavior. Realism is an international theory which argued that states were the central actors of world politics, and the international community was in anarchy, which referred to a lack of a supreme power to regulate the international order and enforce agreements. Anarchy stimulated states to gain more power, material capabilities and assets that every state actor possesses [1] because the incentives of other states are blurred. Eventually, the international community is highly competitive and full of uncertainties: war is always possible. Besides, realism held a pessimistic view of inter-state cooperation: under the competitive, anarchistic environment, states are concerned with the relative gains of their partners and participating states can be "free riders." [2]

For liberalism, it rejects the power politics to be the main and only outcome of world politics, while it promotes international cooperation. To encourage more cooperation and less conflicts, there are three main factors, economic interdependence, democracy, and international institution, to be emphasized. International trade makes states increasingly interconnected with each other, so that they are less likely to go to war. Democratic peace theory conveys the idea that democracies won't go to war with each other. International institutions have an important role to resolve disputes without violence.

While both theories provide a distinct explanation of world politics, there are logical flaws in each of the three liberal theories that potentially downplay the effectiveness of its explanation. We argue that realism better illustrates world politics because the three liberal theories are weak and tenuous, and there is empirical evidence to illustrate that war is still possible.

\section{ARGUMENTS}

\subsection{Economic interdependence}

In international relations theory, one of the most important debates between realists and liberals is over economic interdependence. "Interdependence is a situation in world politics where all actors, including states and non-states, are dependent upon each other" [3].

Realism, especially structural realism, believes that conflicts and war are always possible because of the highly competitive and anarchic system. Anarchy is a situation in which the world lacks a common rule-making authority. Under such an anarchic structure, every state can only rely on themselves and pursue their own interests. To attain security, states must gain as much power as possible. Under this logic, the distribution of power is the root of conflicts and war. "States do not willingly place themselves in situations of increased dependence. In a self-help system, considerations of security subordinate economic gain to political interest." [4]. Realists claim that the most important interest for a state is always security and survival, while economic interdependence can only have weak influence on cooperation. Some empirical evidence in the following part would prove that realism possess stronger explanatory power than liberalism since conflicts and war are always right around the corner.

Liberals believe that wars are usually more costly and risky than trade, and trade is much more costeffective, so countries will not choose to engage in a war if they can receive the resources they need from trade. This especially holds true in the current world: with the development of modern technology, which makes wars even more costly and risky, it is much more rational to choose trade over aggression. According to Richard Rosecrance, a very important reason why this belief holds true is because currently nations often choose to be "trading states", states that focus on promoting wealth through commerce, rather than "territorial states", states that focus on military expansion. Nations understand that "the benefits that one nation gains from trade can also be realized by others." [5] States realize that they can do better by developing a worldwide market for their goods rather than conquering large tracts of land. Therefore, Rosecrance argues that "high interdependence promotes peace by making trading more profitable than invading". [6]

It is true that after industrialization, the cost of a war could be much higher, and economic interdependence becomes a cost-effective way to gain resources and wealth, while wealth would never be the fundamental goal for states, security and survival are. Economic interdependence sometimes promotes cooperation and leads to peace; however, such a peaceful time period is quite hard to sustain. Trade only resolves limited conflicts 
that are related to resource distribution but merely influences other conflicts, like information conflicts and interest conflicts, which is much more common after industrialization. Since the world is extremely competitive, when facing a threat, states will definitely prioritize their security regardless of the cost.

Take the German invasion of the Soviet Union in 1941 as an example to illustrate that economic interdependence is a weak influence on resolving conflicts, and security is still the top priority. Since the autumn of 1939, Germany and the Soviet Union had developed intensive economic cooperation, and it reached the peak in the first half of 1941. Such a relationship has been built credits to the ratification of a German-Soviet credit agreement on August 19, 1939. Besides that, these two states also signed two economic contracts on February 11, 1940, and January 10, 1941. As a result, "even though in 1939 the German Soviet trade capacity of 61 million RM hit the low of the time between the two world wars, it rose to a total turnover of 600 million RM in 1940 and reached a peak of about 425 million RM in the first half of 1941". [7]

Even under such tightened economic cooperation, the Germany and the Soviet Union didn't sustain a peaceful relationship for too long, Germany was prepared to start the attack on the morning of June 22, 1941. From this example, it clearly reflects the security issue and possibility of war hidden from economic interdependence. Since it is hard to predict other states' intentions, realists believe that war is always possible and economic interdependence doesn't play an essential role to avert it.

Not only mentioned the cost effectiveness of trade, Classical liberals, from the other perspective, have argued that economic interdependence and trade are engines for peace because of the creation of a "security community" as well. Deutsch and his collaborators defined a security community as "a group of people" believing "that common social problems must and can be resolved by processes of 'peaceful change'"'[8]. Liberals believe that trade is a mutually beneficial interaction and avoids military conflicts. According to the liberal logic, trade is not simply a commercial activity, while it also causes significant political consequences even with slight changes in trade patterns. Trade and foreign investment could be a media for communicating with other countries, and such communication would effectively resolve conflicts. (Kant). So, economic interdependence will make a large-scale use of violence unthinkable and form the relations of dependable expectations of a peace.

Economic interdependence as a way of communication is not always ideal to resolve problems and attain peace, in fact, it could cause increasingly complicated problems and conflicts under anarchy. For states, international trade brings wealth, which is also a form of power for states to compete. Increased competition on trade among great powers causes the rise and fall in relative power, and such uncertainties end up amplifying the conflicts. As states always want to gain more power, relatively less power would make them feel insecure. So, the economic interdependence causes increased competition and more conflicts if some states choose to cut-offs.

We can better prove the argument from the recent China-United states trade war. The economic competition between China and the U.S. does not only reflect that China challenges the power of the U.S., but they are competing to capture and rule the future core processes in the world market. [9] Trade war happened when the decline of U.S. hegemony and the rise of China, competing for the future makes the situation progressively complicated and uncertain. The main factor and core process for the economic world in the future is technology innovation, like we've experienced in the Information Intelligence and 5G. China and the U.S. both hope to first take control of the future market, so that they would gain or maintain their powers. The US and China, consequently, are competing for the investment of research and development, the protection of intellectual property rights, and the adoption of different foreign policies. As a result, the U.S. and China relationship evolved to the ongoing economic conflicts. We can conclude from the trade war example that the economic interdependence among the great powers is not always leading to an effective communication to avert conflicts, in fact, the competitiveness behind the economic interdependence causes conflicts.

The conflicts increased from trade are not only among great powers, but less powerful states would also get involved because of the asymmetric interdependence. Asymmetrical means one party needs more benefits derived from a relationship more than the other. [10] So, the less dependent actors, usually the great powers, would have more bargaining powers and try to reap more benefits. In this case, the exploitation of less powerful states may also lead to more conflicts.

A good example to show that asymmetrical interdependence would also lead to war is Japan's attacks on the United States in 1941 because of the oil embargos. Japan, an island country, is extremely poor in natural resources, so it must depend on other countries' resources to function well and attain economic growth. Oil, as a strategic resource for airplanes and warships, is one of the most important and vital materials for Japan, and the biggest supplier of it back to that time is the U.S., which supplied Japan with about $80 \%$ of oil. Even though America also depends on Japan for some imports, such interdependency is completely asymmetrical. The US, less dependent one, passed the Export Control Act, cutting oil, iron, and steel exports to Japan in 1940. In addition, "in order to make Japan comply with the demand of the US, the US imposed the oil embargo on 
Japan in 1941, keeping oil, not even one drop, from going to Japan". [11] However, such economic sanctions didn't deter Japan to stop invading China, instead, force it to take more aggressive actions instead. Ultimately, Japanese airplanes carried out a surprise attack on the US military bases in Pearl Harbor, Hawaii. According to this example, it clearly pictures how the great powers exploit vulnerabilities and resentment from the less powerful states causes the war.

\subsection{Democratic Peace Theory}

The second theory, which will be discussed, is the Democratic Peace Theory. Democratic Peace refers to the idea of democracies being more peaceful in their foreign relations. The democratic peace proposition is deeply linked with domestic politics and international relations, such democracies are more likely to cooperate with each other; democracies are more likely to win their wars; leaders initiate conflict to secure their position of power at home; democracies are at war for shorter periods of time; different types of democracies experience different types of conflict behavior, and so on. Historically speaking, the origin of the idea could be traced back to 18 th centuries from enlightenment thinkers such as Immanuel Kant. Till recent decades, it is still one of the main subtopics of Liberalism overall.

When coming to the issue of the definition of "democratic peace", a question that is significant for its fundamentals is "How does one define democracy? In this case, there is a census on the definition of 'liberal Democracy'. Specifically, States (liberal democratic) should include the following elements: Freedom of speech and competitive elections, individual liberty and protection in society, common legislation for the equality of all, and a dominant liberal ideology.

Within the Democratic peace, there are various perspectives for explanation; specifically, it could be explained from theoretical or empirical sides; Speaking from theoretical perspectives, theorists account of relations of peace and democracy, domestic political institutions/norms, or constructed identities. In this case, structural explanation argues the democratic structure that gives citizens influence over government decisions will make it less likely that a democratic leader will wage war with another liberal democracy. This is because the risks/costs of war affect a large segment of the population, and if a war initiated by one person fails, it can lead to the overthrow of the current leader. Another proponent, normative explanation, argues that the democratic political culture encourages peaceful conflict resolution and extends it to other democracies outside the domestic political process, as leaders in both countries have a legitimate expectation that their opponents will also resolve their differences peacefully. In this context, political ideology plays an important role, with democracies (which act in accordance with the wishes of their citizens) being respected and non-democracies (which oppress their citizens) being distrusted.

On the other hand, empirically speaking, one way of explaining is, for "monadic democratic peace", it has been suggested that democracies are more peaceful in their relations with all other countries in the system. Monadic illustrated democracies are less inclined to use force regardless of the type of regime of the hostile state. However, the evidence suggests that liberal democracies are not significantly less likely to go to war with other non-democratic states. Nonetheless, democracies have some important advantages: they are more likely to engage in low-level conflict rather than full-scale war.

Secondly, "dyadic democratic peace", it argues that democracies are more peaceful only in their relations with other democracies. Also, it mentioned that, not only war, but competitions and rivalries could be greatly decreased if the regime changed from non-democracy to democracy. More importantly, there have not been any wars between democracies, despite the augment in the number of democracies in the international system; potentially, it shows that if more countries become democracies, the incidence of conflicts should gradually decrease.

Finally, for "systemic democratic peace", proponents argue that the more democracies there are in a region or international system, the more peaceful that region or international system will be. As what is claimed by realists, and which is what we have discussed above, that is, within the competitive world, war is always possible between states. In this regard, many cases could be explained through a realism perspective clearly, whereas it would not work on liberalism perspectives. Liberalism has long claimed that there is most likely to be peace between the relations of two democracies. However, there are some valid instances of democracies fighting against each other, such as the Six-Day War (The Lebanese Air Force intervened against Israel when both sides were democracies) or the Turkish invasion of Cyprus: The Turkish invasion was a response to the coup d'état. Three days after the invasion, democratic order was restored in the Republic of Cyprus, and the war lasted another month These examples, at least, at the time, both sides were identified as democracies, and yet war still happened. At this point, it is clear that liberalism could not have a clear explanation on instances of wars given above; realism, whereas could give a much better explanation to these examples, and to world politics, regarding terms such as cost-benefits analysis, or relative powers.

As mentioned above, the explanation of democratic peace theory could be structural and normative, the critics of the theory mentioned that the logic of the theory is flawed. The causal logic of institutionalism is challenged by Layne. He argues that Institutional constraints cannot explain democracy and peace. If democratic public opinion really produces the effect it gives, then 
democratic countries will be peaceful in their relations with all countries, whether democratic or not. [12]

Furthermore, Rosato makes an argument against the normative causal logic of the theory, stating that "democratic countries cannot reliably concretize their democratic norms for conflict resolution, and they usually do not trust and respect each other when their interests' conflict." [13]. Lastly, he thinks if the theory is correct, liberal democracies should fight only for causes such as protection of human rights or states' rights.

\section{INTERNATIONAL INSTITUTIONS}

Besides economic interdependence and democratic peace, liberalism also argued that the international institutions can facilitate peace through a set of rules to govern the member states behavior. Institutions are defined as "a set of rules that stipulates in which states should cooperate and compete" [2]. Liberal institutionalism, a branch of liberalism that primarily examines the role of international institutions in the world politics, argues that the international institutions can facilitate inter-state cooperation because of its ability to eliminate the problem of uncertainty and relative gains by enforcing rules to monitor states behavior and solidify states to cooperate and pursue collective gains. [2]. Under this logic, when states are no longer prioritizing selfinterest, they behave less competitive and more cooperative. When states cooperate, it generates a benign environment to prevent the occurrence of war.

However, Realism argues that the international institutions are peripheral and ineffective actors in world politics. According to John Mearsheimer, institutions "are not world governments that would govern state behaviors by enforcing rules and law." [2]. The explanation alludes the great power presence problem, which would incur conflicts: If international institutions can facilitate cooperation and regulation by enforcing rules, great power with absolute advantage can simultaneously neglect the "collective decisions" from a group of minor states and rising power, behaving capriciously. They have no incentive to succumb to the collective interest. Under the deterrence of the great power, the role of international institutions is underplayed. And if the international institutions have impeded great powers to pursue their interest, they would unilaterally initiate war regardless of the presence of institutions.

The invasion of Iraq by the United States in 2003 demonstrates that international institutions are weak in not only regulating great powers, but also promoting peace. Entering the early twenty first century, the United States was already a dominant power with absolute military advantages over other U.N member states. The United States had requested a legalized invasion of Iraq to the United Nations in 2002. But in November, the
United Nations passed the UNSCR 1441, aimed to claim that Iraq has been equipped with ballistic missiles and WMD and it must enforce actions to comply with the disarmament with nine paragraphs of governing conditions within a given time frame [14]. The response from the Security Council did not include permissions for UNSC member states to initiate military intervention. However, the United States circumvented the UNSC and initiated the US-led invasion of Iraq regardless of whether Iraq complied with the UNSC resolution. [14] Unilaterally invading Iraq, the United States simply neglected the UNSC to act upon the U.S self-interest since they targeted Iraq as the "axel evil" after the occurrence of 9.11. Under this context, the United Nations became nonexistent, and its resolution played no role in affecting the U.S eventual decision of initiating the war. The set of rules and regulations might have worked well on regulating a group of minor states which did not have capabilities to dominate, but it could become futile if there were great powers presenting within the international institutions. Hence, the liberal explanation of international institutions in facilitating peace and eliminating war is unconvincing.

Nevertheless, realism comparatively tends to be a better theory in explaining the Iraq war and the relationship between the U.S and the United Nations. Realists argued that international institutions "appear to be unable to reshape state interest.” [15]. Professor Grieco illustrated that because participating in the United Nations did not make the U.S succumb to the collective interests. Under the context of the Iraq war, the interest of the United States was to invade Iraq and hinder it from producing nuclear weapons. In realism's language, the United States was concerned about the relative gain of Iraq because once it possessed nuclear weapons, it would possibly become a military-powerful state that could threaten U.S interest in the Middle East. Driven by its own interest, the U.S planned an attack unilaterally. Conclusively, realism perfectly explained the Iraq war because it proves that even with the presence of international institutions, war is still possible because great powers would always act with their self-interest.

Another liberal flaw about institutions would be that they believe states that share similar ideology are more likely to establish institutions and cooperate with each other. Andrew Moravcsik maintains that the configuration of domestic social identities and values as a basic determinant of state preferences and, therefore, of interstate conflict and cooperation. With underlying patterns of identity, coexistence and even mutual recognition are more likely. Considering this fact, the institution is solid. International institutions are defined as enduring patterns of shared expectations of behavior that have received some degree of formal assent. It is true that cooperation and the presence of institutions are correlated, and institutions are found where cooperation is high. However, the relationship of cooperation and 
institution is not that the latter advances former, but that the latter is the product of the seek for former in states. Given the fact that it is predictable that institutions are related to increasing cooperation, only if states want to cooperate with each other and seek the goal that institution will help them reach, they will establish institutions. In conclusion, it is not institutions which have the power to increase cooperation, but the demands of states, which establish institutions and thus become the foundation of institutions. Once states want to start war, the presence of institutions will be meaningless. The failure of the League of Nations would illustrate this. After WWI, many states wanted to keep peace with each other because of the great loss in WWI. In this condition, the league of nations plays a role in the initial stage. However, the effect is not caused by the institution itself, but the demands of states. And when some states wanted war to benefit more, the league of nations played little role eventually.

\section{DISCUSSION}

While the three liberal theories are all criticized, they each possess unique arguments to refute realism as well: first, to challenge the structural realism' explanation of state behavior, which focuses on military and economic power, the model of 'Complex Interdependence' was developed by Robert $\mathrm{O}$ Keohane and Joseph S. Nye. They didn't reject realism, rather they raised the concern that in some situation's realists' explanation is not sufficient. Complex interdependence theory pointed out the complex ways that states and other actors mutually dependent on each other, resulting in the vulnerability of each other's action and sensitivity of each other's needs. They admit the high politics of national security and military power remain important and relevant, but argue that economic, social, and environmental issues - low politics - are high priorities on the international agenda as well. [3] Keohane also pointed out that multiple channels play an important role to transform the payoff structure and promote cooperation. Realism does not deny the cooperation among states; however, they contend that cooperation is hard to achieve and maintain. Realists stressed more on the relative gains instead of the absolute gains. When expected gains derived from the cooperation, how to divide such gains will link to the relative position in the distribution of power. It is also uncertain about other states' intentions if they gained more power. Therefore in this anarchic world, states feel insecure about how other states will act, and conflicts and war are always possible.

Secondly, the theory of liberal democratic peace provides clear moral guidance for political action, and that explains the conditions of peacekeeping, but it also serves the additional purpose of guiding national international policies. As shown above, peace is extended according to the theory, there is more peace between democracies, or, at least, much lower likelihood of fullscale war between each. However, Rosato makes an argument against the normative causal logic of the theory, stating that "democratic countries cannot reliably concretize their democratic norms for conflict resolution, and they usually do not trust and respect each other when their interests' conflict." [13]. Lastly, he thinks if the theory is correct, liberal democracies should fight only for causes such as protection of human rights or states' rights.

While realism displays the weakness of international institutions in promoting peace and hampering war, Liberal institutionalism will respond that states are eligible to overcome the problem of great power presence and minimizing the likelihood of conflict through the idea of "strategic restraint" and "open hegemony". Even though incorporating great powers would decentralize the power of international institutions, international institutions constrain great powers in practicing their power and minor states could make alliances with the great powers to decentralize their practice of power and engage in decision-making process, which is defined as "strategic restraint." [16]. According to Ikenberry, institutional agreements can restrain great powers for two reasons. First, hegemonic states would prefer maintaining their current dominant status by cooperating with the participating states to ensure their interests. Second, minor states within the international institution utilizes "bonding" and "binding" agreements with the great powers to unveil and participate in their decision-making processes. [16] Minor states are willing to "bind" with the great power to not only increase their security but also indirectly restrain the great power by earning a "voice" in influencing their actions and behaviors. The practice of "bonding" would also increase the pellucidity of actions and decisions, providing the right to monitor great power behaviors. [16]

Nonetheless, publicizing the hegemonic behaviors of the great powers and binding with them to increase their relative power in affecting their decision-making process is not tantamount to eliminating the possibility of conflict. Logically, binding with a great power also does not indicate that the regulations of institutions are effective in containing great powers by increasing the interdependence between it and minor states. Recalling the Iraq war example, Britain, one of the members of both UNSC and NATO, coordinated with the U.S by enjoining armies. Britain was both a relative minor state and binding state with the U.S. But it does not behave like "strategic restraint". Rather, Britain supported the invasion of Iraq by standing with the U.S. The collaboration between Britain and the U.S illustrated that the effectiveness of the "binding" strategy is highly contingent. Sometimes binding can inversely help facilitate conflict rather than prohibit it. Realism, on the other hand, neglects this contingency because it assumes all states are acting on their self-interest. 
Nevertheless, liberals argue that even in wartime, some states can maintain the institution and cooperate with each other. As Thucydides claims, oligarchic states like Sparta and democrats states like Athens form opponent alliances during the Peloponnesian War. In the seventeenth and eighteenth centuries, absolutist kings fought to establish dynastic claims and religious rule; in the nineteenth century, they cooperated to preserve monarchical rule against societal pressures for reform. In the twentieth century, the cold war witnessed the form of NATO and WTO which are representative of distinct ideology.

However, though some states share similar ideology and thus are more likely to cooperate, the essence of world politics is considering one's own interest and fearing other power. Similar configuration social identities and values could help states keep institutions only if they want to benefit from the institution. If some factors fundamental for a state are negatively affected by this institution and cooperation, the institution and relationship will break up soon, even causing no matter how close they were.

\section{CONCLUSION}

Overall, we argue that realism better explains world politics because the three variants of liberal theory are feeble in comprehensively explaining world politics because the possibility of war is always possible regardless of the presence of international institutions, economic interdependence. Whereas realism is eligible to account for political incidents that liberalism fails to address. However, a better theory does not completely negate the relatively less convincing theory because the purpose of the paper is to decide which theory "better" explains world political events, but not attempting to argue that which theory is effective and which theory is futile.

Our conclusion suggests that realism prone to better explain world politics. Indeed, contemporary world politics does behave like a realist. When the pandemic first exploded, the world was competing for vaccine inventions. And the intensified relationship between China and the U.S overshadows the power struggle between the two biggest economies in the world. The world is not as harmonious and cooperative as what liberals suggest. Rather, it is more competitive and pernicious.

\section{REFERENCES}

[1] Mearsheimer, J.J. (2001). The tragedy of Great Power politics. New York: Norton.

[2] Mearsheimer, J.J. (1994). The False Promises of International Institutions. International Security.19(3),5-49. https://www.jstor.org/stable/2539078?seq=1\#metad ata_info_tab_contents

[3] Rana, Waheeda. "Theory of Complex Interdependence: A Comparative Analysis of Realist and Neoliberal Thoughts." International Journal of Business and Social Science, 2015, www.ijbssnet.com/journals/Vol_6_No_2_February _2015/33.pdf.

[4] Waltz, Kenneth. "Chapter 6.” Theory of International Politics, by Kenneth N. Waltz, Waveland Press, 2010, p. 107.

[5] Copeland, Dale C. "Economic interdependence and war: a theory of trade expectations." International Security, vol. 20, no. 4, spring 1996, pp. 5+. Gale Academic

OneFile, link.gale.com/apps/doc/A18348487/AON $\mathrm{E}$ ?u=anon $9 \mathrm{e} 71 \mathrm{adef} \& \operatorname{sid}=$ googleScholar $\& \mathrm{xid}=\mathrm{d} 11$ $25 \mathrm{a} 23$.

[6] Rosecrance, R. N. (1987). The rise of the trading state: Commerce and conquest in the modern world. Amazon. https://www.amazon.com/Rise-TradingState-CommerceConquest/dp/0465070361.

[7] Schwendemann, H. (2016, March 31). Heinrich Schwendemann. Cahiers du Monde Russe.https://www.persee.fr/doc/cmr_12526576_1995_num_36_1_2425.

[8] Deutsch, Karl W.; et al. (1957). Political Community and the North Atlantic Area: International Organization in the Light of Historical Experience. Princeton: Princeton University Press.

[9] Flint, C., \& XIAOTONG, Z. (2021). (PDF) Why and why is the US-CHINA trade war? Journal of World Trade.

[10] Wagner, R. H. (2009, May 22). Economic interdependence, bargaining power, and political influence: International organization. Cambridge Core.

https://www.cambridge.org/core/journals/internatio nal-organization/article/economic-interdependencebargaining-power-and-politicalinfluence/732BACA6F5015A38D78D34F6C7C37 E02

[11] “CHAPTER EIGHT Japan's Attack on Pearl Harbor, 1941." Blinders, Blunders, and Wars: What America and China Can Learn, by Bonny Lin et al., RAND Corporation, 2014, pp. 93-106.

[12] Layne, C. (1994). Kant or Cant: The Myth of the Democratic Peace. International Security, 19(2), 549. doi:10.2307/2539195 
[13] Rosato, S. (2003). The Flawed Logic of Democratic Peace Theory. American Political Science Review, 97(4), 585-602. doi:10.1017/S0003055403000893

[14] Dunne, Michael. (2003). The United States and Iraq: "Multilateralism of a kind", international affairs. 79(2), 270-276.

https://academic.oup.com/ia/article/79/2/257/24178 34 ? $\log$ in $=$ true

[15] Grieco, J. (1988). Anarchy and the limits of Cooperation: A realist critique of the newest liberal institutionalism. International Organization, 42 (3),485-507.

https://www.cambridge.org/core/journals/internatio nal-organization/article/anarchy-and-the-limits-ofcooperation-a-realist-critique-of-the-newestliberalinstitutionalism/B15341ABF136D039DBC1D99A 4179A64E

[16] Ikenberry, J. (1999). Institutions, Strategic restraint, and the Persistence of American Postwar Order. International Security, 23(3), 43-78. https://direct.mit.edu/isec/article/23/3/43/11615/Ins titutions-Strategic-Restraint-and-the 